Check for updates

Cite this: RSC Adv., 2019, 9, 11912

Accepted 29th March 2019

DOI: 10.1039/c9ra00731h

rsc.li/rsc-advances
Received 28th January 2019

\section{Mesoporous $\mathrm{MnOx}-\mathrm{CeO}_{2}$ composites for $\mathrm{NH}_{3}-$ SCR: the effect of preparation methods and a third dopant $\uparrow$}

\begin{abstract}
Li Weiman, (iD abcd Liu Haidi ${ }^{\text {a }}$ and Chen Yunfa (D) *ad
In this study, different preparation methods including an oxalate route, a nano-casting strategy and a traditional co-precipitation route were applied to obtain $\mathrm{MnOx}-\mathrm{CeO}_{2}$ mixed oxides for selective catalytic reduction (SCR) of $\mathrm{NO}$ with $\mathrm{NH}_{3}$. The catalyst prepared from the oxalate route showed improved performance for $\mathrm{NOx}$ conversion and $\mathrm{SO}_{2}+\mathrm{H}_{2} \mathrm{O}$ durability. To further improve the $\mathrm{SO}_{2}$ and $\mathrm{H}_{2} \mathrm{O}$ resistance of catalysts, ternary oxides were prepared from the oxalate route. The catalysts were studied by X-ray diffraction (XRD), Brunauer-Emmett-Teller (BET) surface area analysis, X-ray photoelectron spectroscopy (XPS), $\mathrm{H}_{2}$ temperature-programmed reduction $\left(\mathrm{H}_{2}-\mathrm{TPR}\right), \mathrm{NH}_{3}$ temperatureprogrammed desorption ( $\mathrm{NH}_{3}-\mathrm{TPD}$ ), $\mathrm{SO}_{2}$ temperature-programmed desorption ( $\mathrm{SO}_{2}-\mathrm{TPD}$ ), and in situ diffuse reflectance infrared fourier transform spectroscopy (in situ DRIFTS). The nickel-manganesecerium ternary oxide showed the best $\mathrm{SO}_{2}$ and $\mathrm{H}_{2} \mathrm{O}$ durability. The reason can be ascribed to its smaller pores, amorphous structure, and moderate amount of surface $\mathrm{Mn}^{3+}$ /oxygen species, which could decrease chemical adsorption of $\mathrm{SO}_{2}$.
\end{abstract}

\section{Introduction}

Nitrogen oxides (NOx), emitted from combustion of fossil fuels in industrial stationary sources, have caused a series of environmental problems such as acid rain, haze, and ozone depletion. Selective catalytic reduction of $\mathrm{NOx}$ by ammonia $\left(\mathrm{NH}_{3}-\right.$ SCR) is one of the most promising NOx abatement technologies. The widely used catalyst in $\mathrm{NH}_{3}-\mathrm{SCR}$ is $\mathrm{V}_{2} \mathrm{O}_{5}-\mathrm{WO}_{3}\left(\mathrm{MoO}_{3}\right) / \mathrm{TiO}_{2}$, whose optimum working temperature is higher than $350{ }^{\circ} \mathrm{C}$. In practical application, the SCR reactor is usually located downstream of dust and $\mathrm{SO}_{2}$ removing modules to avoid catalyst deactivation from dust, $\mathrm{SO}_{2}$ and other poisoners. As a result, the temperature of flue gas is usually lower than $300^{\circ} \mathrm{C}$, and the flue gas has to be reheated to meet the $\mathrm{V}-\mathrm{W}-\mathrm{Ti}$ working temperature, which will increase the cost of deNOx. Therefore, a better choice is to develop catalysts with high deNOx efficiency, high resistance to water vapor/ $/ \mathrm{SO}_{2}$, and a low working temperature window.

\footnotetext{
${ }^{a}$ State Key Laboratory of Multi-phase Complex Systems, Institute of Process Engineering, Chinese Academy of Sciences, Beijing 100190, China. E-mail: chenyf@ ipe.ac.cn

${ }^{b}$ University of Chinese Academy of Sciences, No. 19A Yuquan Road, Beijing 100049, China

${ }^{c}$ Zhongke Langfang Institute of Process Engineering, Langfang Economic \& Technical Development Zone, Fenghua Road No. 1, Hebei Province, China

${ }^{d}$ CAS Center for Excellence in Urban Atmospheric Environment, Xiamen 361021, China

$\dagger$ Electronic supplementary information (ESI) available. See DOI: 10.1039/c9ra00731h
}

Ce-Mn composites have been reported widely for their excellent low temperature deNOx efficiency and high $\mathrm{N}_{2}$ selectivity. The catalytic ability of Ce-Mn composites is related to the pore structure, specific area, and redox behavior. ${ }^{1-3}$ For example, $\mathrm{MnOx}-\mathrm{CeO}_{2}$ nanosphere catalyst showed superior performance compared to its counterpart $\mathrm{MnOx}-\mathrm{CeO}_{2}$ without any defined structural morphology. ${ }^{4} \mathrm{MnOx}-\mathrm{CeO}_{2}$ hollow nanotube synthesized through the interfacial oxidation-reduction reaction showed $96 \%$ NOx conversion at $100{ }^{\circ} \mathrm{C}$, and the authors attributed to the uniform distribution of active species and the hollow porous architectures which provided huge specific surface area and sufficient acidic sites. ${ }^{5}$ However, the activity of $\mathrm{MnOx}-\mathrm{CeO}_{2}$ composites is still low in the presence of $\mathrm{SO}_{2}$ and $\mathrm{H}_{2} \mathrm{O}$. Lots of efforts have been done to improve $\mathrm{SO}_{2}$ and $\mathrm{H}_{2} \mathrm{O}$ resistance of $\mathrm{MnOx}-\mathrm{CeO}_{2}$ composites. For example, adding a third dopant ( $\mathrm{Sn}, \mathrm{Cr}, \mathrm{W}, \mathrm{Eu}$ etc.) into $\mathrm{MnOx}-\mathrm{CeO}_{2}$ composites can further improve the deNOx efficiency and $\mathrm{SO}_{2}$ resistance. ${ }^{6-9}$ Cobalt or nickel doped $\mathrm{MnOx}-\mathrm{CeO}_{2}$ catalysts showed high SCR activity and good tolerance of $\mathrm{SO}_{2}$, and the authors suggested different SCR reaction pathways and mechanisms of $\mathrm{SO}_{2}$ tolerance between $\mathrm{Co} / \mathrm{Ni}$ doped and un-doped $\mathrm{MnOx}-\mathrm{CeO}_{2} \cdot{ }^{10}$ Mesoporous catalysts have been proved a good choice to improve $\mathrm{SO}_{2}$ resistance. ${ }^{11}$ Zha prepared a MnCeW catalyst on mesoporous $\mathrm{TiO}_{2}$ spheres, and the catalyst showed excellent SCR activity in a wide temperature range. ${ }^{9} \mathrm{Fe}_{2} \mathrm{O}_{3}$ promoted halloysite-supported $\mathrm{CeO}_{2}-\mathrm{WO}_{3}$ catalysts showed improved $\mathrm{NOx}$ reduction in the presence of $\mathrm{SO}_{2}$, and the authors confirmed that the increase of Brønsted acid site derived from $\mathrm{Fe}_{2} \mathrm{O}_{3}$ promotion is the main cause. ${ }^{12}$ 
Based on previous studies, the catalytic performance of $\mathrm{NH}_{3}$ SCR activity, including NOx conversion efficiency, $\mathrm{N}_{2}$ selectivity and $\mathrm{H}_{2} \mathrm{O}+\mathrm{SO}_{2}$ resistance are mainly determined by following factors: pore structure and surface area, the distribution of manganese and cerium states, and the active oxygen species including adsorbed oxygen, oxygen vacancy and lattice oxygen, as well as surface acidity. Inspired by the above studies, we have fabricated $\mathrm{MnOx}-\mathrm{CeO}_{2}$ with different pore structures by various methods, and the relationship of $\mathrm{NH}_{3}$-SCR ability and structure was discussed. To further improve the $\mathrm{H}_{2} \mathrm{O}+\mathrm{SO}_{2}$ resistance of the catalysts, nickel/cobalt was introduced to the $\mathrm{MnOx}-\mathrm{CeO}_{2}$ catalysts, and the catalytic performance was evaluated.

\section{Experimental section}

\subsection{Catalysts preparation}

All chemical reagents used in this work including $\mathrm{Mn}(\mathrm{ac})_{2} \cdot 4 \mathrm{H}_{2} \mathrm{O}$ (99.0\%), $\mathrm{Ce}(\mathrm{ac})_{3} \cdot 0.5 \mathrm{H}_{2} \mathrm{O} \quad(99.0 \%), \quad \mathrm{Co}(\mathrm{ac})_{2} \cdot 4 \mathrm{H}_{2} \mathrm{O} \quad(99.0 \%)$, $\mathrm{Ni}(\mathrm{ac})_{2} \cdot 4 \mathrm{H}_{2} \mathrm{O}(99.0 \%), \mathrm{C}_{2} \mathrm{H}_{2} \mathrm{O}_{4} \cdot 2 \mathrm{H}_{2} \mathrm{O}(99.5 \%), \mathrm{Mn}\left(\mathrm{NO}_{3}\right)_{2}(50 \%$ wt), $\mathrm{Ce}\left(\mathrm{NO}_{3}\right)_{3} \cdot 6 \mathrm{H}_{2} \mathrm{O}, \mathrm{Co}\left(\mathrm{NO}_{3}\right)_{2} \cdot 6 \mathrm{H}_{2} \mathrm{O}, \mathrm{Ni}\left(\mathrm{NO}_{3}\right)_{2} \cdot 6 \mathrm{H}_{2} \mathrm{O}$ and $\mathrm{NaOH}$ were purchased from Xilong Cop. (China) and used without further purification. To prepare $\mathrm{MnOx}-\mathrm{CeO}_{2}$ composites with different pore structures, an oxalate route, a nano-casting strategy and a simple precipitation method were applied.

In an oxalate route, calculated metal salts (the molar ratio of Mn and Ce was $6: 4$ ) were dissolved in deionized water at room temperature, labeled as solution A. Then, $\mathrm{C}_{2} \mathrm{H}_{2} \mathrm{O}_{4} \cdot 2 \mathrm{H}_{2} \mathrm{O}$ (the molar ratio of $\mathrm{C}_{2} \mathrm{H}_{2} \mathrm{O}_{4} \cdot 2 \mathrm{H}_{2} \mathrm{O}$ to total metals is 1.2) was dissolved in ethanol, labeled as solution $\mathrm{B}$. The mixtures of $\mathrm{A}$ and $\mathrm{B}$ were stirred for $24 \mathrm{~h}$. The precipitates were washed, dried, and finally calcined at $550{ }^{\circ} \mathrm{C}$ for $4 \mathrm{~h}$. The sample was labeled as $6 \mathrm{Mn} 4 \mathrm{Ce}-\mathrm{O}$. Nickel or cobalt doped $\mathrm{MnOx}-\mathrm{CeO}_{2}$ composite was prepared as the same procedure. The samples were denoted as $1 \mathrm{Ni6Mn} 3 \mathrm{Ce}-$ $\mathrm{O}$ and $1 \mathrm{Co6} \mathrm{Mn} 3 \mathrm{Ce}-\mathrm{O}$, respectively.

In a nano-casting route, KIT-6 silica was employed as a hard template, and the $\mathrm{MnOx}-\mathrm{CeO}_{2}$ catalyst was synthesized by a simple "two-solvent" approach. KIT-6 silica was prepared as previously reported studies. ${ }^{13}$ In a typical procedure, $1.0 \mathrm{~g}$ KIT-6 was suspended in $80 \mathrm{ml} n$-hexane and stirred at room temperature for $2 \mathrm{~h}$. Then a mixed solution of $\mathrm{Mn}\left(\mathrm{NO}_{3}\right)_{2}$ and $\mathrm{Ce}\left(\mathrm{NO}_{3}\right)_{3}$ was added slowly with vigorous stirring. After stirred overnight, the mixture was filtered and dried at $80{ }^{\circ} \mathrm{C}$ for $24 \mathrm{~h}$. The obtained powder was calcined at $550{ }^{\circ} \mathrm{C}$ for $4 \mathrm{~h}$, with a heating rate of $2{ }^{\circ} \mathrm{C} \min ^{-1}$ in air. Finally, the sample was treated three times with a $2 \mathrm{M} \mathrm{NaOH}$ solution, washed to $\mathrm{pH} \sim 7$ and dried at $80^{\circ} \mathrm{C}$. The product was denoted as $6 \mathrm{Mn} 4 \mathrm{Ce}-\mathrm{N}$.

As a comparison, the third $\mathrm{MnOx}-\mathrm{CeO}_{2}$ sample was synthesized by a co-precipitation method using $\mathrm{NH}_{3} \mathrm{H}_{2} \mathrm{O}$ as precipitant, and the sample was labeled as $6 \mathrm{Mn} 4 \mathrm{Ce}-\mathrm{C}$.

\subsection{Catalytic activity tests}

Before SCR activity test, the catalysts were crushed and sieved to 40-60 mesh. A fixed-bed quartz flow reactor was used to perform SCR activity test. The typical reactant gas contained $200 \mathrm{ppm}$ NOx, 200 ppm $\mathrm{NH}_{3}, 5 \% \mathrm{O}_{2}, 100$ ppm $\mathrm{SO}_{2}$ (when used), 5 vol\% $\mathrm{H}_{2} \mathrm{O}$ (when used) and balance of $\mathrm{N}_{2}$. In a typical experiment,
$100 \mathrm{mg}$ catalyst was used, corresponding to gas volume hourly space velocity (GHSV) of $72000 \mathrm{~h}^{-1}$. The temperature range was set to 100-300 ${ }^{\circ} \mathrm{C}$. An FTIR spectrometer (Bruker Vertex 70 spectrometer, USA) equipped with a heated, multiple path gas cell $(10 \mathrm{~m})$ was used to collect the FTIR spectra. The NOx conversion and $\mathrm{N}_{2}$ selectivity were calculated as follows:

$$
\operatorname{NOx} \text { conversion }(\%)=\frac{[\mathrm{NO}]_{\text {in }}-[\mathrm{NO}]_{\text {out }}}{[\mathrm{NO}]_{\text {in }}} \times 100 \%,
$$

$$
\begin{aligned}
& \mathrm{N}_{2} \text { selectivity }(\%) \\
& \qquad=\frac{[\mathrm{NO}]_{\text {in }}+\left[\mathrm{NH}_{3}\right]_{\text {in }}-\left[\mathrm{NO}_{2}\right]_{\text {out }}-2\left[\mathrm{~N}_{2} \mathrm{O}\right]_{\text {out }}}{[\mathrm{NO}]_{\text {in }}+\left[\mathrm{NH}_{3}\right]_{\text {in }}} \times 100 \%
\end{aligned}
$$

\subsection{Characterization}

XRD patterns were recorded on a PANalytical X'Per PRO X-ray diffraction using Ni filtered $\mathrm{Cu} \mathrm{K} \alpha(\lambda=0.15418 \mathrm{~nm})$ radiation at $40 \mathrm{kV}$ and $30 \mathrm{~mA}$, in $2 \theta$ from $5^{\circ}$ to $90^{\circ}$ with a scanning step of $0.0334^{\circ}$. The specific surface area and pore size distributions of all catalysts were obtained according to the Brunauer-EmmettTeller (BET) and Barrett-Joyner-Halenda (BJH) methods, respectively, using $\mathrm{N}_{2}$ adsorption-desorption method on an automatic surface analyzer (SSA-7300, BJ-Builder, China) at 77 K. Each sample was pre-degassed at $150{ }^{\circ} \mathrm{C}$ for $3 \mathrm{~h}$. Surface species of as-prepared catalysts were determined by X-ray photoelectron spectroscopy (XPS) using a XLESCALAB $250 \mathrm{Xi}$ electron spectrometer (Thermo Scientific, USA) with monochromatic $\mathrm{Al} \mathrm{K} \alpha$ radiation $(1486.6 \mathrm{eV})$.

$\mathrm{H}_{2}$ temperature-programmed reduction $\left(\mathrm{H}_{2}-\mathrm{TPR}\right)$ was conducted on a Micromeritics Chemisorb 2720 analyzer (Micromeritics, USA) at a heating rate of $10{ }^{\circ} \mathrm{C} \min ^{-1}$ with $5 \% \mathrm{H}_{2} / \mathrm{Ar}$ gas. The $\mathrm{H}_{2}$ consumption was recorded continuously to investigate reduction abilities. $\mathrm{NH}_{3}$ temperature-programmed desorption ( $\mathrm{NH}_{3}$-TPD) was performed on a Micromeritics Autochem II 2920 analyzer (Micromeritics, USA). The catalysts were firstly heated to $300{ }^{\circ} \mathrm{C}$ for $1 \mathrm{~h}$ in helium, and then cooled down to $50{ }^{\circ} \mathrm{C}$. After saturated in pure $\mathrm{NH}_{3}$ for $30 \mathrm{~min}$, the samples were purged in pure helium for $1 \mathrm{~h}$ to remove the physically adsorbed $\mathrm{NH}_{3}$. The TPD curve was finally recorded in helium from $50{ }^{\circ} \mathrm{C}$ to $600{ }^{\circ} \mathrm{C}$ at a heating rate of $10^{\circ} \mathrm{C} \mathrm{min}^{-1}$. $\mathrm{SO}_{2}$ temperature-programmed desorption ( $\mathrm{SO}_{2}$-TPD) was performed on a TP5080B apparatus (Tianjin XQ, China). $50 \mathrm{mg}$ of 40-60 mesh catalysts was firstly heated to $300{ }^{\circ} \mathrm{C}$ for $1 \mathrm{~h}$ in 30 $\mathrm{ml} \mathrm{min}^{-1}$ helium, and then cooled to $200{ }^{\circ} \mathrm{C}$. The catalysts was saturated in $2000 \mathrm{ppm} \mathrm{SO}_{2}$ for $1 \mathrm{~h}$, and then purged with 30 $\mathrm{ml} \mathrm{min}{ }^{-1}$ helium for $1 \mathrm{~h}$ to remove residue $\mathrm{SO}_{2}$ at $200^{\circ} \mathrm{C}$. At last, the catalyst was heated from $200{ }^{\circ} \mathrm{C}$ to $850{ }^{\circ} \mathrm{C}$ in helium at $10{ }^{\circ} \mathrm{C} \min ^{-1}$.

A Bruker Vertex 70 spectrometer (Bruker, USA) equipped with diffuse reflectance accessory (PIKE, and MCT/A detector cooled by liquid nitrogen) was used for recording the in situ DRIFT spectra of the samples. Twenty $\mathrm{mg} \mathrm{KBr}$ powder was placed under proper amount of samples, and a specially made steel stick was used to smash the sample to a flat surface. The 
sample was pretreated at $300{ }^{\circ} \mathrm{C}$ for $2 \mathrm{~h}$ in $\mathrm{N}_{2}\left(50 \mathrm{ml} \mathrm{min}{ }^{-1}\right)$. The reaction system was cooled to $200{ }^{\circ} \mathrm{C}$ in $\mathrm{N}_{2}$, and the spectra were collected as background. The spectra were recorded by accumulating 32 scans at a resolution of $4 \mathrm{~cm}^{-1}$.

\section{Results and discussion}

\section{$3.1 \mathrm{NH}_{3}$-SCR performance}

All composites prepared by different methods were tested for $\mathrm{NH}_{3}$-SCR in temperature range of $100-350{ }^{\circ} \mathrm{C}$, as shown in Fig. 1A. The NOx conversion of all catalysts first increased and then decreased. The NOx conversion rates at the whole temperature range of the three catalysts followed the sequence of $6 \mathrm{Mn} 4 \mathrm{Ce}-\mathrm{O}>6 \mathrm{Mn} 4 \mathrm{Ce}-\mathrm{C}>6 \mathrm{Mn} 4 \mathrm{Ce}-\mathrm{N}$. The NOx conversion of $6 \mathrm{Mn} 4 \mathrm{Ce}-\mathrm{O}$ reached its maximum of $99 \%$ at $\sim 170{ }^{\circ} \mathrm{C}$; and it's NO conversion rate remained $>80 \%$ at the temperature range of 120-275 ${ }^{\circ} \mathrm{C}$. The NOx conversion of $6 \mathrm{Mn} 4 \mathrm{Ce}-\mathrm{C}$ was slightly lower than that of $6 \mathrm{Mn} 4 \mathrm{Ce}-\mathrm{O}$. The catalyst prepared from nanocasting route showed the worst catalytic performance. Resistance to $\mathrm{H}_{2} \mathrm{O}$ and $\mathrm{SO}_{2}$ is an important factor that to be concerned in the evaluation of $\mathrm{NH}_{3}$-SCR catalysts, as there is more or less $\mathrm{SO}_{2}$ and $\mathrm{H}_{2} \mathrm{O}$ in gas that to be managed. The $\mathrm{H}_{2} \mathrm{O}+$ $\mathrm{SO}_{2}$ resistance of three samples is shown in Fig. 1B. After $\mathrm{H}_{2} \mathrm{O}+$ $\mathrm{SO}_{2}$ was introduced into flue gas, the NOx conversion rate of
$6 \mathrm{Mn} 4 \mathrm{Ce}-\mathrm{O}, 6 \mathrm{Mn} 4 \mathrm{Ce}-\mathrm{N}$ and $6 \mathrm{Mn} 4 \mathrm{Ce}-\mathrm{C}$ deceased to $\sim 70 \%$, $\sim 62.5 \%$ and $\sim 59 \%$, respectively. This indicated that different structure of catalysts had a profound effect on resistance of $\mathrm{H}_{2} \mathrm{O}$ and $\mathrm{SO}_{2}$.

Addition of transition metal oxides (CrOx, ${ }^{14} \mathrm{NiO},{ }^{10,15-17}$ $\mathrm{Co}_{3} \mathrm{O}_{4},{ }^{10} \mathrm{SnO}_{2},{ }^{18,19}$ et al.) into $\mathrm{MnOx}$ or $\mathrm{CeO}_{2}$ were shown to improve the SCR activity in presence of $\mathrm{SO}_{2}$ and $\mathrm{H}_{2} \mathrm{O}$, by increasing the surface acidity concentration of Lewis or Brønsted acid sites. ${ }^{16,18,20}$ Based on above results, the $\mathrm{H}_{2} \mathrm{O}$ and $\mathrm{SO}_{2}$ resistance of sample prepared from oxalate route was better than other two samples. Therefore, we prepared Co/Ni doped $\mathrm{MnOx}-\mathrm{CeO}_{2}$ composites by oxalate route to further improve their resistance to $\mathrm{H}_{2} \mathrm{O}$ and $\mathrm{SO}_{2}$. As shown in Fig. 1C, addition of nickel or cobalt can both increase the NOx conversion rate at temperature range of $100-280{ }^{\circ} \mathrm{C}$. For example, the NOx conversion of $1 \mathrm{Ni} 6 \mathrm{Mn} 3 \mathrm{Ce}-\mathrm{O}$ and $1 \mathrm{Co} 6 \mathrm{Mn} 3 \mathrm{Ce}-\mathrm{O}$ were $99 \%$ at $200{ }^{\circ} \mathrm{C}$, slightly higher than that of $6 \mathrm{Mn} 4 \mathrm{Ce}-\mathrm{O}\left(\sim 96 \%\right.$ at $\left.200{ }^{\circ} \mathrm{C}\right)$. Besides, the $\mathrm{N}_{2}$ selectivity of $6 \mathrm{Mn} 4 \mathrm{Ce}-\mathrm{O}$ was lower than those of 1Ni6Mn3Ce-O and 1Co6Mn3Ce-O (Fig. 1C). The above results showed that addition of nickel or cobalt slightly improves the SCR activity and $\mathrm{N}_{2}$ selectivity. The $\mathrm{H}_{2} \mathrm{O}$ and $\mathrm{SO}_{2}$ resistance of transition metal oxide doped composites were shown in Fig. 1D. With co-existence of $\mathrm{H}_{2} \mathrm{O}$ and $\mathrm{SO}_{2}$, NOx conversion decreased sharply to $70 \%, 80 \%$ and $20 \%$ over $6 \mathrm{Mn} 4 \mathrm{Ce}-\mathrm{O}, 1 \mathrm{Ni} 6 \mathrm{Mn} 3 \mathrm{Ce}-\mathrm{O}$
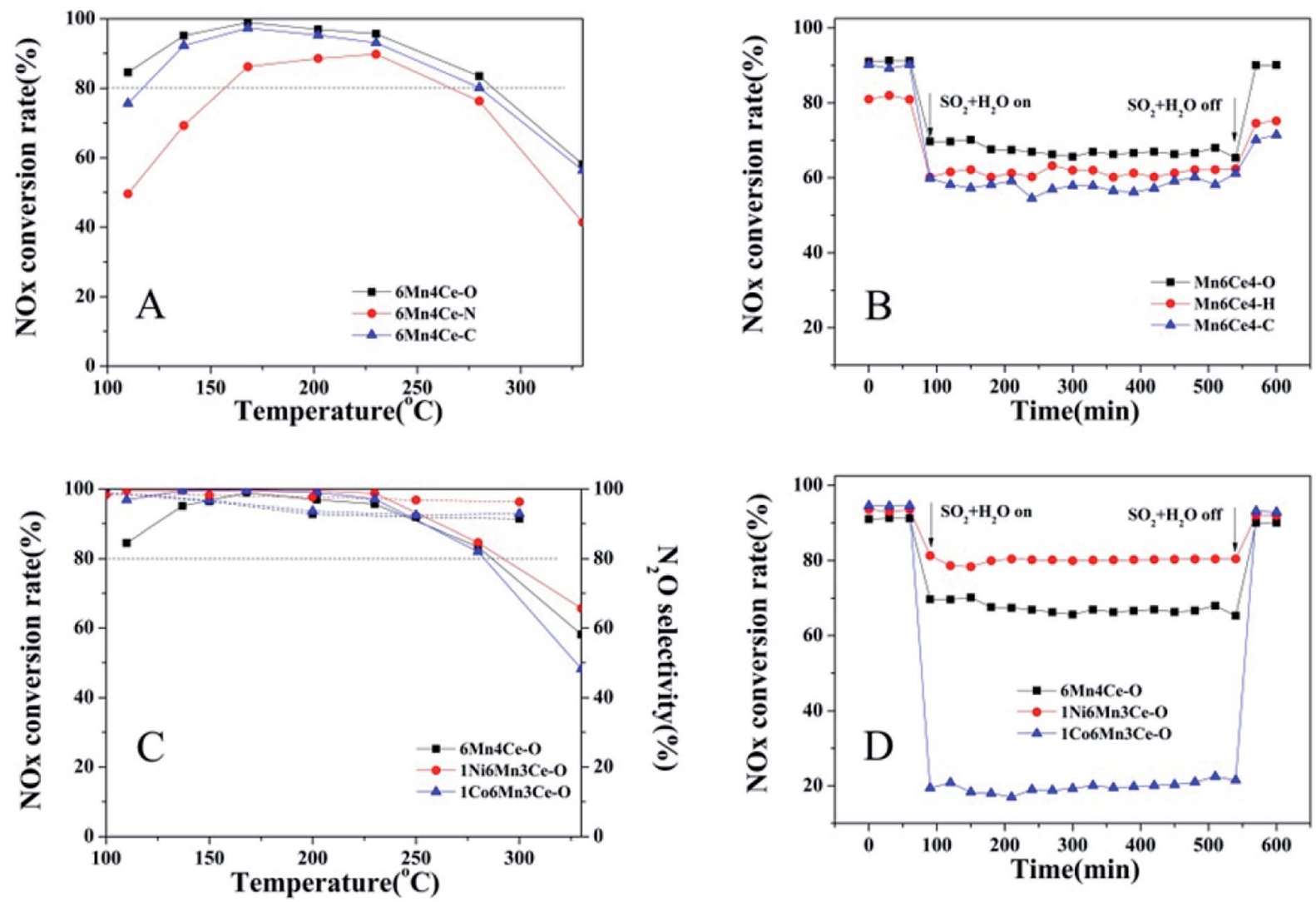

Fig. 1 (A) NOx conversion as a function of temperature over $\mathrm{MnOx}-\mathrm{CeO}_{2}$ prepared by different methods; (B) $\mathrm{H}_{2} \mathrm{O}+\mathrm{SO}_{2}$ resistance over prepared by different methods at $200{ }^{\circ} \mathrm{C}$; (C) NOx conversion as a function of temperature over nickel/cobalt doped $\mathrm{MnOx}-\mathrm{CeO}{ }_{2} ;(\mathrm{D}) \mathrm{H}_{2} \mathrm{O}+$ $\mathrm{SO}_{2}$ resistance over nickel/cobalt doped samples by oxalate method at $200{ }^{\circ} \mathrm{C}$; (reaction conditions: $\left[\mathrm{NOx}^{-}=\left[\mathrm{NH}_{3}\right]=200 \mathrm{ppm},\left[\mathrm{O}_{2}\right]=5 \mathrm{vol} \%\right.$, $\left[\mathrm{SO}_{2}\right]=100 \mathrm{ppm},\left[\mathrm{H}_{2} \mathrm{O}\right]=5 \mathrm{vol} \%$ (when used), $\mathrm{N}_{2}$ as balance gas, flow rate $=100 \mathrm{ml} \mathrm{min}{ }^{-1}, \mathrm{GHSV}=60000 \mathrm{~h}^{-1}$ ). 
and 1 Co6mn3Ce-O, respectively. When $\mathrm{H}_{2} \mathrm{O}$ and $\mathrm{SO}_{2}$ were cutoff, the deNOx activity of $6 \mathrm{Mn} 4 \mathrm{Ce}-\mathrm{O}, 1 \mathrm{Ni} 6 \mathrm{Mn} 3 \mathrm{Ce}-\mathrm{O}$ and $1 \mathrm{Co} \mathrm{Mn} 3 \mathrm{Ce}-\mathrm{O}$ resumed. In previous studies, $\mathrm{MnOx}-\mathrm{CeO}_{2}$ composite exhibited low $\mathrm{SO}_{2}$ tolerance because of sulfate species formation. Therefore, many efforts have been done to improve the $\mathrm{SO}_{2}$ resistance of $\mathrm{MnOx}-\mathrm{CeO}_{2}$ catalysts. For example, novel $\mathrm{MnOx}-\mathrm{CeO}_{2}$ nano-sphere catalyst showed improved $\mathrm{SO}_{2}$ tolerance than $\mathrm{MnOx}-\mathrm{CeO}_{2}$ catalyst without defined structural morphology. ${ }^{4} \mathrm{CeO}_{2}-\mathrm{MnOx}$ showed relatively good resistance to $\mathrm{SO}_{2}$ because of its core-shell structure. ${ }^{21}$ In our study, both preparation methods and addition of a third dopant were help to improve the resistance to $\mathrm{SO}_{2}$ and $\mathrm{H}_{2} \mathrm{O}$. This phenomenon illustrated structure, as well as different interaction among third dopants and $\mathrm{Mn}-\mathrm{Ce}$ composites may play important roles in $\mathrm{NH}_{3}$-SCR, which will further be discussed in following parts.

\subsection{Structural properties}

3.2.1 XRD and BET analysis. The XRD patterns of all samples were shown in Fig. 2. The diffraction peaks of $6 \mathrm{Mn} 4 \mathrm{Ce}-\mathrm{O}$ mainly represented $\mathrm{CeO}_{2}$ (JCPDF\#34-0394) and $\mathrm{Mn}_{2} \mathrm{O}_{3}$ (JCPDF\#41-1442). While the diffraction peaks of 6Mn4Ce-N and $6 \mathrm{Mn} 4 \mathrm{Ce}-\mathrm{C}$ exhibited broad reflections of $\mathrm{CeO}_{2}$, no obvious peaks related to MnOx.

The diffraction peaks of $1 \mathrm{Ni} 6 \mathrm{Mn} 3 \mathrm{Ce}-\mathrm{O}$ and $1 \mathrm{Co} 6 \mathrm{Mn} 3 \mathrm{Ce}-\mathrm{O}$ exhibited broad reflections of $\mathrm{CeO}_{2}$, no obvious peaks related to $\mathrm{MnOx}$, NiO or cobalt oxides. Similar results ${ }^{22}$ were reported in the case of $\mathrm{Ni}(0.4)-\mathrm{MnOx}$ spinel. It is commonly accepted than amorphous structure is easy to embed and intercalate protons rapidly, ${ }^{23}$ therefore promoting adsorption/desorption and redox reaction on the surface of catalysts. ${ }^{2324}$ In our study, although the deNOx efficiency and $\mathrm{N}_{2}$ selectivity of catalysts were similar, the $\mathrm{SO}_{2}+\mathrm{H}_{2} \mathrm{O}$ resistance varied a lot. It can be concluded that amorphous structure caused by addition of a third dopant may be responsible for the good performance of catalysts.

The $\mathrm{N}_{2}$-adsorption-desorption isotherms and corresponding Barrett-Joyner-Halenda $(\mathrm{BJH})$ pore size distribution curves for catalysts were shown in Fig. 3 (inset). The isotherms of all catalysts showed a characteristic type IV pattern, with a hysteresis loop of type $\mathrm{H}_{2}$ in the IUPAC classification, indicating the existence of meso-pores and micro-pores. At low $P / P_{0}$, the isotherm curve of $6 \mathrm{Mn} 4 \mathrm{Ce}-\mathrm{O}$ had a relatively lower slope than those of other catalysts, indicating its higher degree of crystallinity, consistent with XRD results. As shown in Fig. 3 (A, inset) and Table 1, the specific surface area of 6Mn4Ce-N $\left(152.116 \mathrm{~m}^{2}\right.$ $\left.\mathrm{g}^{-1}\right)$ was higher than $6 \mathrm{Mn} 4 \mathrm{Ce}-\mathrm{O}\left(116.678 \mathrm{~m}^{2} \mathrm{~g}^{-1}\right)$ and $6 \mathrm{Mn} 4 \mathrm{Ce}-$ C $\left(77.269 \mathrm{~m}^{2} \mathrm{~g}^{-1}\right)$; while the pore diameter followed the sequence of $6 \mathrm{Mn} 4 \mathrm{Ce}-\mathrm{N}<6 \mathrm{Mn} 4 \mathrm{Ce}-\mathrm{O}<6 \mathrm{Mn} 4 \mathrm{Ce}-\mathrm{C}$. This result showed that the specific surface area is not positively correlated with the NOx conversion, similar to the report from Qi. ${ }^{25}$ Mesoporous materials present lots of edges and corners for adsorption of reactants; and the pores facilitate mass transfer at the gas-solid phase boundary. ${ }^{26}$ Large surface area contributed more active sites, which would facilitate the adsorption of reactants. However, the $\mathrm{SO}_{2}$ and $\mathrm{H}_{2} \mathrm{O}$ in flue gas may also occupy the active sites of catalysts, leading to a drop of SCR conversion. The smaller pores in catalysts from oxalate routes may possibly inhibit the reaction of $\mathrm{NOx}, \mathrm{NH}_{3}$ with $\mathrm{SO}_{2}$ and $\mathrm{H}_{2} \mathrm{O}$. Although $6 \mathrm{Mn} 4 \mathrm{Ce}-\mathrm{O}$ has a higher degree of crystallinity, which may not facilitate the synergistic effect between elements, the smaller pores in it can balance its structure.

For catalysts from a same oxalate route, a third dopant did not change the specific surface area significantly as shown in Table 1. However, the pore diameter of $6 \mathrm{Mn} 4 \mathrm{Ce}-\mathrm{O}$ and 1Co6Mn3Ce-O were among 1.5-2.5 nm. While for $1 \mathrm{Ni} 6 \mathrm{Mn} 3 \mathrm{Ce}-$ $\mathrm{O}$, the pore size distribution was among $1.5-2 \mathrm{~nm}$ and 2.5$10 \mathrm{~nm}$, similar to previous study. ${ }^{27}$ This indicated addition of nickel into $\mathrm{MnOx}-\mathrm{CeO}_{2}$ could change its pore structure, leading to a combination of macropores and mesopores. According to literature, ${ }^{28}$ the release of gaseous $\mathrm{H}_{2} \mathrm{O}$ and $\mathrm{COx}$ will create pores during the decomposition of oxalate chains chelated in corresponding precursors. In our study, nickel may regulate gas release during the thermo-decomposition precursors.

3.2.2 Surface composition analysis. The XPS results were shown in Fig. 4, and all spectra were calibrated with C1s (284.8
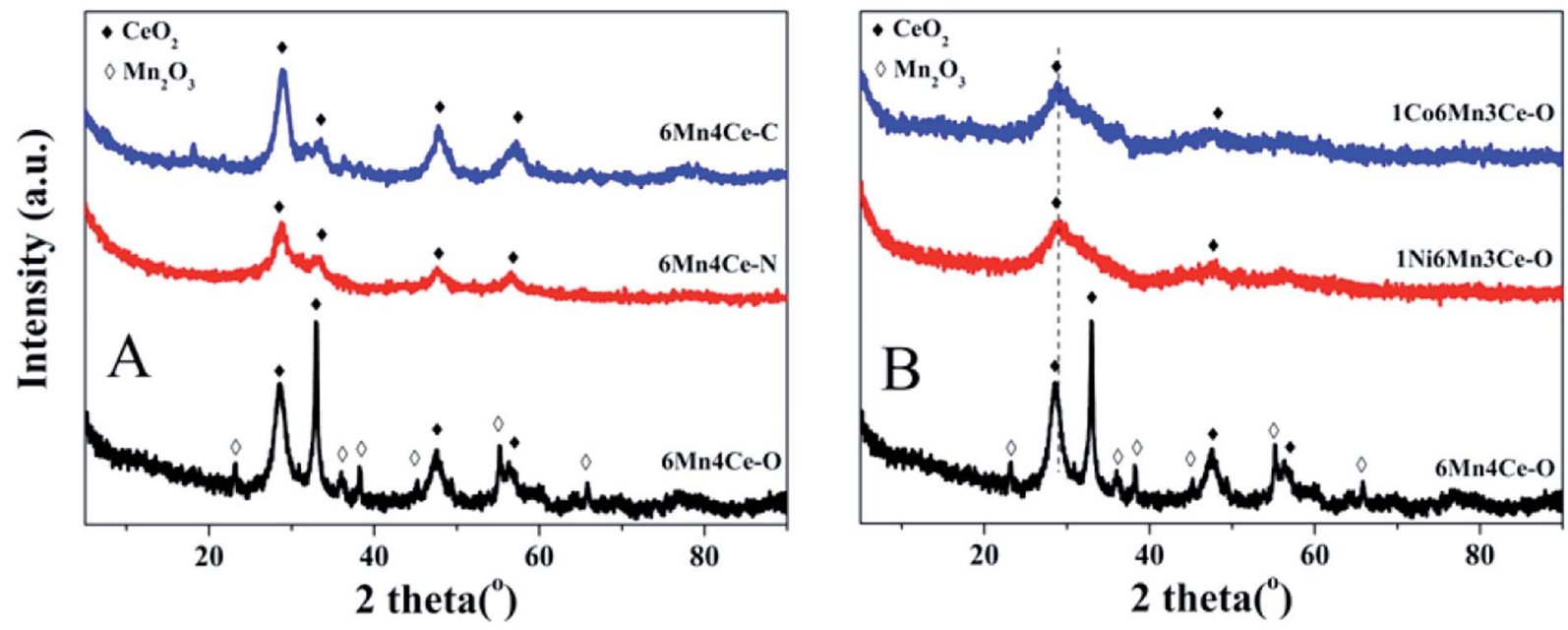

Fig. 2 XRD patterns of as-prepared samples, (A) samples from different methods, and (B) nickel or cobalt doped samples from oxalate route. 

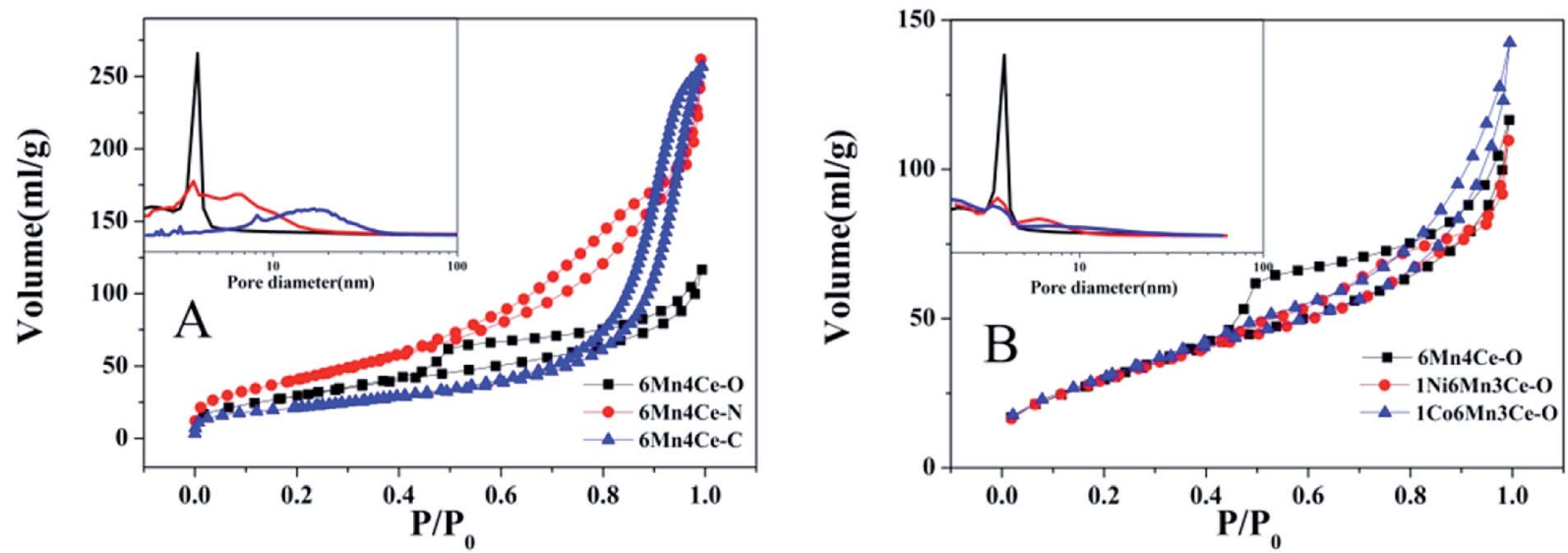

Fig. $3 \quad \mathrm{~N}_{2}$ adsorption/desorption isotherms and pore size distribution (inset) for samples (A) samples from different methods, and (B) nickel or cobalt doped samples from oxalate route.

Table 1 The structural data for all catalysts

\begin{tabular}{lrlr}
\hline & BET $\left(\mathrm{m}^{2} \mathrm{~g}^{-1}\right)$ & $\begin{array}{l}\text { Pore volume } \\
\left(\mathrm{ml} \mathrm{g}^{-1}\right)\end{array}$ & $\begin{array}{l}\text { Average pore } \\
\text { diameter }(\mathrm{nm})\end{array}$ \\
\hline 6Mn4Ce-O & 116.678 & 0.1686 & 6.5 \\
6Mn4Ce-N & 152.116 & 0.3955 & 10.7 \\
6Mn4Ce-C & 77.269 & 0.4036 & 20.6 \\
1Ni5Mn4Ce-O & 113.258 & 0.1428 & 6.0 \\
1Co5Mn4Ce-O & 116.926 & 0.1937 & 7.5
\end{tabular}

$\mathrm{eV})$ before analysis. O1s spectra were fitted into two peaks. The peak centered at $\sim 529.2-529.7 \mathrm{eV}$ was related to surface lattice oxygen (denoted as $\mathrm{O}_{\text {latt }}$ ), and the peak at higher binding energy $(\sim 532.4 \mathrm{eV})$ was ascribed to surface chemisorbed oxygen (including adsorbed oxygen, hydroxyl and carbonate, denoted as $\left.\mathrm{O}_{\text {ads }}\right)$. Compared with $6 \mathrm{Mn} 4 \mathrm{Ce}-\mathrm{O}$ and $6 \mathrm{Mn} 4 \mathrm{Ce}-\mathrm{N}$, the $\mathrm{O}_{\text {latt }}$ peak of 6Mn4Ce-C shifted to lower binding energy (529.7 eV to $529.2 \mathrm{eV}$ ). This phenomenon indicated that different synthesis method can regulate element valence. The relative ratios of $\mathrm{O}_{\text {ads }} / \mathrm{O}_{\text {latt }}$ were $1.96,1.26$ and 1.09 for $6 \mathrm{Mn} 4 \mathrm{Ce}-\mathrm{O}, 6 \mathrm{Mn} 4 \mathrm{Ce}-\mathrm{N}$ and $6 \mathrm{Mn} 4 \mathrm{Ce}-\mathrm{C}$, respectively. $\mathrm{O}_{\text {ads }}$ are considered as the active sites for SCR, because they can provide acid sites to adsorb $\mathrm{NH}_{3}$ to form $\mathrm{NH}_{4}{ }^{+}$or $\mathrm{NH}_{3}(\mathrm{ads}){ }^{29}$ From this point of view, more $\mathrm{O}_{\text {ads }}$ species lead to improved activity and good $\mathrm{H}_{2} \mathrm{O}$ and $\mathrm{SO}_{2}$ durability. The $\mathrm{H}_{2} \mathrm{O}$ and $\mathrm{SO}_{2}$ durability sequence of $1 \mathrm{Ni} 5 \mathrm{Mn} 3 \mathrm{Ce}-\mathrm{O}$, $6 \mathrm{Mn} 4 \mathrm{Ce}-\mathrm{O}$, and $1 \mathrm{Co} 6 \mathrm{Mn} 3 \mathrm{Ce}-\mathrm{O}$ was consistent with $\mathrm{O}_{\mathrm{ads}} / \mathrm{O}_{\text {latt }}$ ratio $(1 \mathrm{Ni} 5 \mathrm{Mn} 3 \mathrm{Ce}-\mathrm{O}>6 \mathrm{Mn} 4 \mathrm{Ce}-\mathrm{O}>1 \mathrm{Co} 6 \mathrm{Mn} 3 \mathrm{Ce}-\mathrm{O})$. Again, this indicated oxalate route and introduction of nickel leading to more surface defects. Previous studies have convinced that surface chemisorbed oxygen were more active to oxidize NO than lattice oxygen. And the higher ratio of surface chemisorbed oxygen facilitate the "fast-SCR" reaction. ${ }^{10}$

The Mn2p spectra were deconvoluted into three peaks located at 641.0, 642.4 and $643.8 \mathrm{eV}$, which can be assigned to $\mathrm{Mn}^{2+}, \mathrm{Mn}^{3+}$ and $\mathrm{Mn}^{4+}$, respectively. ${ }^{30,31}$ The percentage of $\mathrm{Mn}$ species with different valences was calculated, and the results were shown in Table 2. Although a higher oxidation state of manganese species was better for redox properties, ${ }^{32}$ moderate ratio of $\mathrm{Mn}^{3+} / \mathrm{Mn}^{4+}$ was help to improve $\mathrm{SO}_{2}+\mathrm{H}_{2} \mathrm{O}$ resistance. In our study, the surface $\mathrm{Mn}^{3+}$ species was related to $\mathrm{SO}_{2}+\mathrm{H}_{2} \mathrm{O}$ resistance. As shown in Table 2, the sequence of $\mathrm{Mn}^{3+}$ species was $6 \mathrm{Mn} 4 \mathrm{Ce}-\mathrm{O}>6 \mathrm{Mn} 4 \mathrm{Ce}-\mathrm{N}>6 \mathrm{Mn} 4 \mathrm{Ce}-\mathrm{C}$, consistent with catalytic sequence in Fig. 1B. For samples from oxalate route, the sequence of $\mathrm{Mn}^{3+}$ species was $1 \mathrm{Ni} 6 \mathrm{Mn} 4 \mathrm{Ce}-\mathrm{O}>6 \mathrm{Mn} 4 \mathrm{Ce}-\mathrm{O}>$ 1Co6Mn4Ce-O, indicating a third dopant can regulate the surface manganese species. Based on the above various characterization studies, it was observed that different preparation method or a third dopant can regulate interaction among Mn, $\mathrm{Ce}, \mathrm{Ni} / \mathrm{Co}$ oxides, which would bring about an appropriate content of active $\mathrm{Mn}^{3+}$ and oxygen species on the surface of catalyst.

3.2.3 Temperature programming. Redox properties are crucial for the $\mathrm{NH}_{3}$-SCR activities, and $\mathrm{H}_{2}$-TPR spectra were employed to investigate redox properties of the catalysts. The $\mathrm{H}_{2}$ consumption as a function of reaction temperature was shown in Fig. 5. For 6Mn4Ce-O, three reduction peaks were observed. The peak centered at $286^{\circ} \mathrm{C}$ could be assigned to reduction of $\mathrm{Mn}^{4+} \rightarrow \mathrm{Mn}^{3+}$, and the peak centered at $243{ }^{\circ} \mathrm{C}$ could be ascribed to $\mathrm{Mn}^{3+} \rightarrow \mathrm{Mn}^{2+}$. The broad peak at $381{ }^{\circ} \mathrm{C}$ was related to the reduction of surface oxygen of $\mathrm{CeO}_{2}\left(\mathrm{Ce}^{4+} \rightarrow \mathrm{Ce}^{3+}\right) .^{33}$ There was no significant peaks related to $\mathrm{Mn}^{3+} \rightarrow \mathrm{Mn}^{2+}$ for samples prepared from nano-casting route and co-precipitation route, consistent with XPS and XRD results, indicating their less portion of $\mathrm{Mn}^{3+}$. While for $1 \mathrm{Ni6Mn} 3 \mathrm{Ce}-\mathrm{O}$ and $1 \mathrm{Co} 6 \mathrm{Mn} 3 \mathrm{Ce}-\mathrm{O}$, all peaks shifted to lower temperature range, indicating the incorporation of $\mathrm{Ni} / \mathrm{Co}, \mathrm{Mn}$ and Ce enhances the reducibility of catalyst.

$\mathrm{NH}_{3}$-TPD was employed to investigate $\mathrm{NH}_{3}$ adsorption, therefore to examine the acidic sites on different catalysts, as presented in Fig. 6 . There were two main peaks on all spectra. The peak at the mid-temperature range $\left(100-400{ }^{\circ} \mathrm{C}\right)$ is related to the desorption of $\mathrm{NH}_{3}$ coordinated to Lewis acid sites, and the peak at high-temperature range $\left(400-550{ }^{\circ} \mathrm{C}\right)$ is considered to the desorption of $\mathrm{NH}_{3}$ coordinated to Brønsted acid sites. ${ }^{15,34}$ Compared with catalysts prepared from nano-casting and precipitation method, the peak related to Lewis acid sites of 

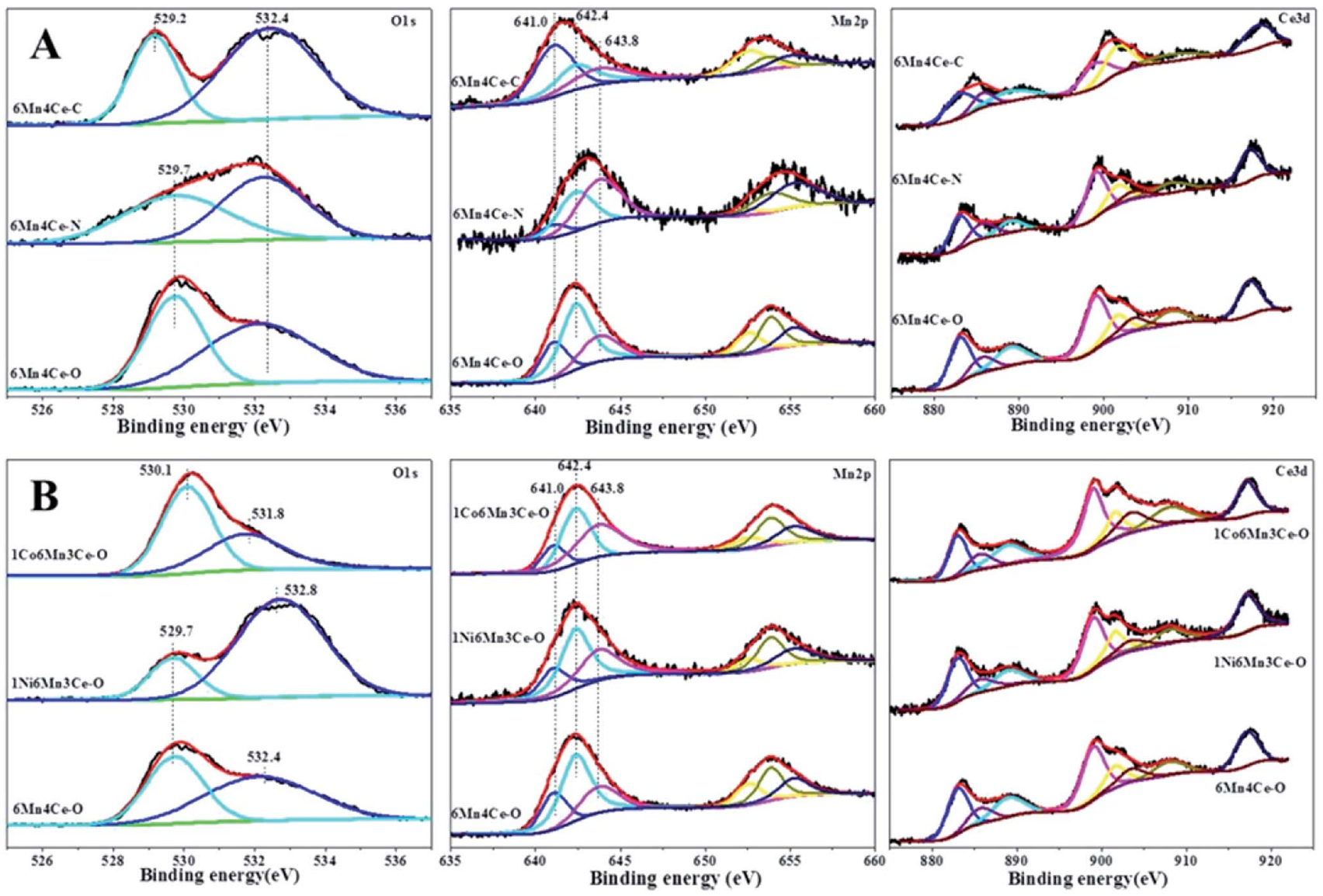

Fig. 4 O1s, Mn2p and Ce3d spectra of (A) samples from different methods, and (B) nickel or cobalt doped samples from oxalate route.

Table 2 The relative ratio of different elements for all catalysts

\begin{tabular}{llrlll}
\hline & $\mathrm{O}_{\text {ads }} / \mathrm{O}_{\text {latt }}$ & $\mathrm{Mn}^{2+}(\%)$ & $\mathrm{Mn}^{3+}(\%)$ & $\mathrm{Mn}^{4+}(\%)$ & $\mathrm{B} / \mathrm{L}$ \\
\hline 6Mn4Ce-O & 1.96 & 21.89 & 55.34 & 22.77 & 0.47 \\
6Mn4Ce-N & 1.26 & 9.17 & 39.08 & 51.75 & 0.37 \\
6Mn4Ce-C & 1.09 & 47.31 & 30.17 & 22.52 & 0.29 \\
1Ni5Mn4Ce-O & 3.91 & 20.64 & 46.73 & 32.63 & 0.95 \\
1Co5Mn4Ce-O & 0.71 & 14.56 & 39.98 & 45.46 & 0.39
\end{tabular}

$6 \mathrm{Mn} 4 \mathrm{Ce}-\mathrm{O}$ moved toward lower temperature range, indicating the existence of weak Lewis adsorption sites. As described above, samples from oxalate route may have more acidic sites during the decomposition of precursors. The ratios of $\mathrm{NH}_{3}$ adsorption on Brønsted acid site to Lewis acid sites of different catalysts are shown in Table 2. Oxalate route was easier to produce more Brønsted acid sites than other two methods. And addition of nickel can greatly increase the ratio of Brønsted acid/Lewis acid sites. Based on the above various characterization studies, it was observed that different preparation method or a third dopant could regulate interaction among $\mathrm{Mn}, \mathrm{Ce}, \mathrm{Ni}$ / Co oxides, which would bring about an appropriate content of active $\mathrm{Mn}^{3+}$ and oxygen species on the surface of catalyst.

As samples from the oxalate route had different resistance to $\mathrm{SO}_{2}$ and $\mathrm{H}_{2} \mathrm{O}, \mathrm{SO}_{2}$-TPD tests were performed on these three samples, and the results were shown in Fig. 7. There were two main desorption peaks in the temperature range of $300-600{ }^{\circ} \mathrm{C}$, and $650-800{ }^{\circ} \mathrm{C}$, labeled as 1 and 2 , respectively. The small and broad peak in area 1 was reported to be assigned to desorption of $\mathrm{SO}_{2}$ adsorbed on the surface of catalysts. ${ }^{35}$ In this paper, the area labeled 1 of $1 \mathrm{Ni5Mn} 4 \mathrm{Ce}$ was slightly smaller than the other two catalysts, which indicated less $\mathrm{SO}_{2}$ adsorption on it. The main peak at $650-580{ }^{\circ} \mathrm{C}$ was associated to desorption of $\mathrm{SO}_{2}$ released from the decomposition of metal sulfates. The area 2 of 1Ni5Mn4Ce was much smaller compared with others, which indicated nickel adding can inhabit formation of metal sulfates. Similar conclusion could be achieved from the TG-DTA test of samples after $\mathrm{SO}_{2}+\mathrm{H}_{2} \mathrm{O}$ resistance experiments, as shown in ESI. $\dagger$

\subsection{In situ DRIFTs}

To better understand gas adsorption on different catalysts from oxalate route, in situ DRIFTs was conducted, and the results were shown in Fig. 8. Fig. 8A showed in situ DRIFTS spectra of $\mathrm{NH}_{3}+\mathrm{O}_{2}$ adsorbed on three samples. The bands at 1235, 1565, $1610 \mathrm{~cm}^{-1}$ were ascribed to $\mathrm{NH}_{3}$ coordinated on Lewis acid sites. $^{36}$ The band at $1457 \mathrm{~cm}^{-1}$ was due to the symmetric bending vibration of $\mathrm{NH}_{4}{ }^{+}$chemosorbed on the Brønsted acid sites. ${ }^{18}$ Meanwhile, a band at $3230 \mathrm{~cm}^{-1}$ was due to the $\mathrm{N}-\mathrm{H}$ stretching vibrations of the $\mathrm{NH}_{4}{ }^{+} \cdot{ }^{37}$ Comparing with 1Co6Mn3Ce-O, 6Mn4Ce-O and $1 \mathrm{Ni6Mn} 3 \mathrm{Ce}-\mathrm{O}$ revealed more 

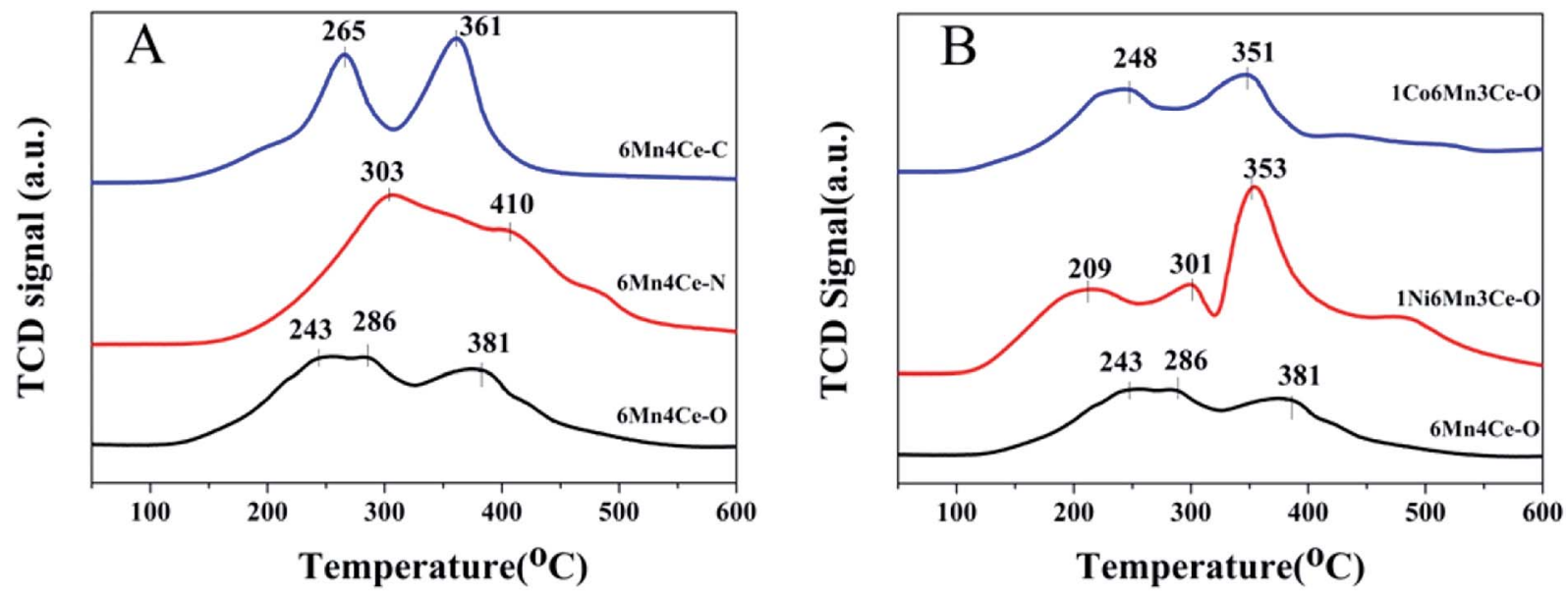

Fig. $5 \quad \mathrm{H}_{2}$-TPR spectra of (A) samples from different methods, and (B) nickel or cobalt doped samples from oxalate route.
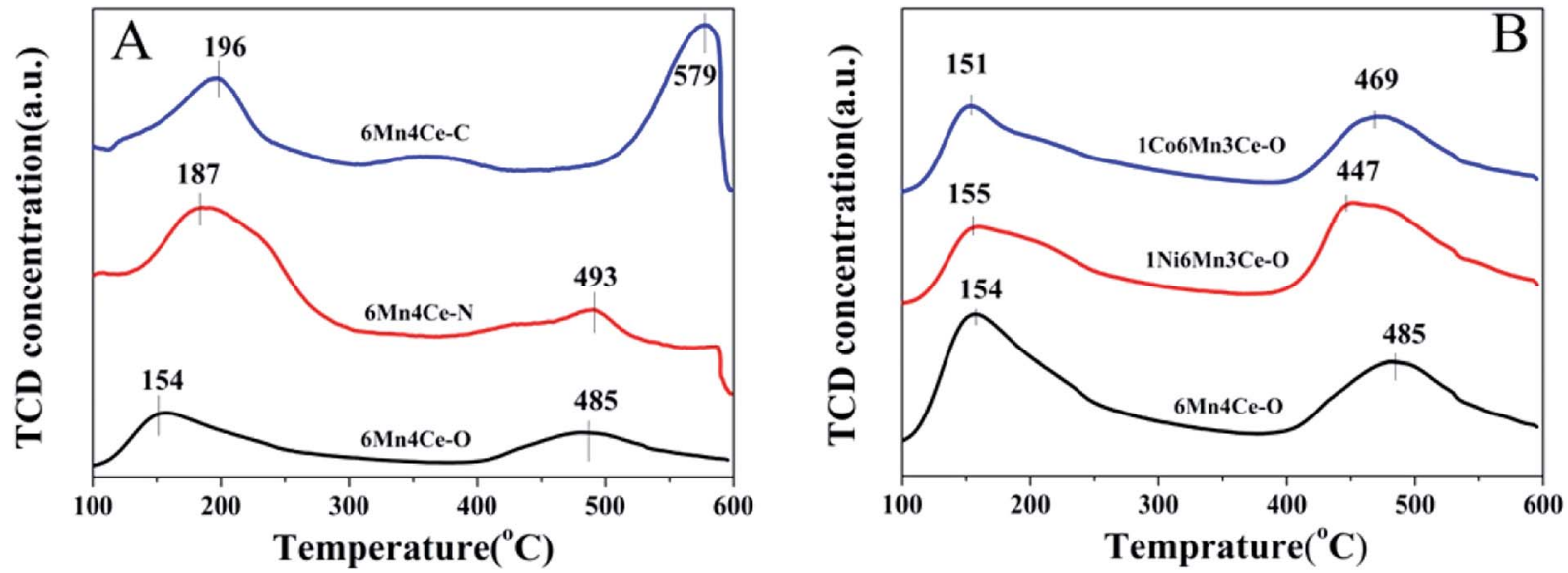

Fig. $6 \mathrm{NH}_{3}$-TPD spectra of (A) samples from different methods, and (B) nickel or cobalt doped samples from oxalate route.

Brønsted acid sites, consistent with $\mathrm{NH}_{3}$-TPD results. Wu obtained the same result that addition of nickel could significantly improve the Brønsted acid sites on $\mathrm{FeVO}_{4} / \mathrm{TiO}_{2}{ }^{38}$

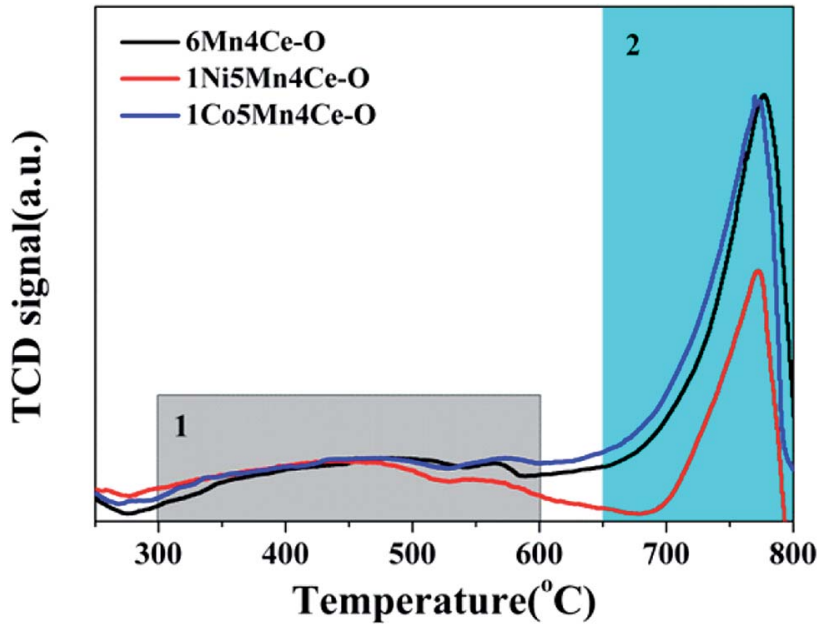

Fig. $7 \mathrm{SO}_{2}$-TPD spectra samples from an oxalate route.
Fig. 8B displayed the in situ DRIFTs spectra of NOx $+\mathrm{O}_{2}$ adsorption on catalysts at $200{ }^{\circ} \mathrm{C}$. The peaks centered at $1606 \mathrm{~cm}^{-1}$ can be ascribed to bridging monodentate nitrates, and peaks centered at 1267, 1209, 1568 and $1540 \mathrm{~cm}^{-1}$ were assigned to bidentate nitrates. ${ }^{39}$ It was noteworthy that bidentate nitrates species on $1 \mathrm{Ni6Mn3Ce-O}$ were more than those on other catalysts, indicating nickel addition increased NO uptake. However, cobalt doping leaded to the decrease of bands related to bidentate nitrates, indicating its suppression to NO adsorption.

As $1 \mathrm{Ni6Mn3Ce-O}$ showed the best $\mathrm{H}_{2} \mathrm{O}$ and $\mathrm{SO}_{2}$ resistance, the in situ DRIFTs were further displayed to understand the mechanism, and the results were shown in Fig. 9. The 1Ni6Mn3Ce-O was firstly exposed to $\mathrm{NH}_{3}$ for $60 \mathrm{~min}$, and then $\mathrm{SO}_{2}$ and $\mathrm{H}_{2} \mathrm{O}$ was introduced to the reaction gas. The bands corresponding to $\mathrm{NH}_{3}$ (a) was quickly diminished, and new bands related to $\mathrm{SO}_{2}$ adsorption appeared, as shown in Fig. 9A. While $1 \mathrm{Ni6Mn} 3 \mathrm{Ce}-\mathrm{O}$ was firstly exposed to $\mathrm{NO}+\mathrm{O}_{2}$ for $60 \mathrm{~min}$, and then $\mathrm{SO}_{2}$ was introduced to the reaction gas, no new bands appeared, which indicated that $\mathrm{NO}$ was more easily adsorbed on the surface of catalysts. The $1 \mathrm{Ni6Mn} 3 \mathrm{Ce}-\mathrm{O}$ was exposed to $\mathrm{NH}_{3}$ $+\mathrm{NO}+\mathrm{O}_{2}$ at $200{ }^{\circ} \mathrm{C}$ for $60 \mathrm{~min}$, and there were peaks related to 

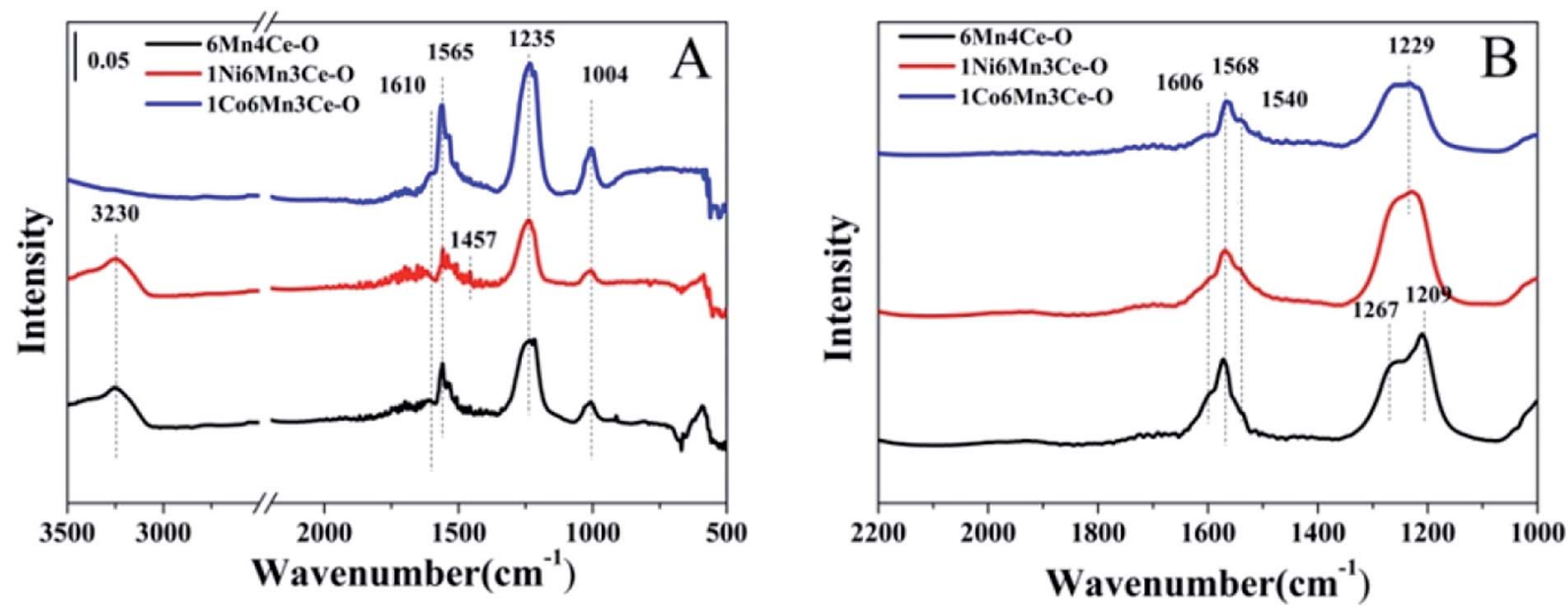

Fig. 8 In situ DRIFTS of samples under $\mathrm{NH}_{3}+$ air (A) and $\mathrm{NOx}+$ air (B) for $1 \mathrm{~h}$ and then purged by helium for 30 min at $200{ }^{\circ} \mathrm{C}$.

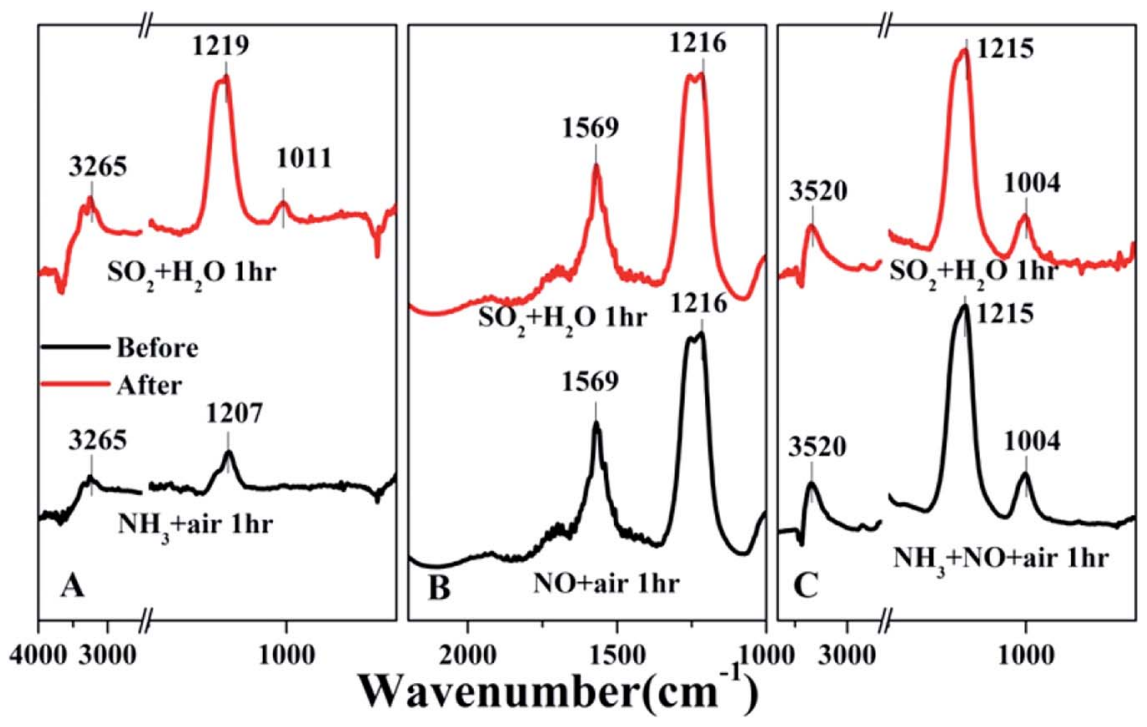

Fig. 9 In situ DRIFTS of $1 \mathrm{Ni} 6 \mathrm{Mn} 3 \mathrm{Ce}-\mathrm{O}$ under $\mathrm{NH}_{3}+$ air (A), $\mathrm{NOx}+$ air (B) and $\mathrm{NOx}+\mathrm{NH}_{3}+\mathrm{O}_{2}(\mathrm{C})$ for $1 \mathrm{~h}$ and then $\mathrm{SO}_{2}$ and $\mathrm{H}_{2} \mathrm{O}$ were introduced into the mixed gas for $1 \mathrm{~h}$ at $200^{\circ} \mathrm{C}$.

$\mathrm{NH}_{3}$ and NOx adsorption, indicating the co-adsorption of $\mathrm{NH}_{3}$ and NOx. After 100 ppm $\mathrm{SO}_{2}$ and $\mathrm{H}_{2} \mathrm{O}$ were added for another $60 \mathrm{~min}$, no new bands appeared and the intensity of the original bands remained unchanged. This indicated that $\mathrm{SO}_{2}$ and $\mathrm{H}_{2} \mathrm{O}$ in the flue gas had no impact on $\mathrm{NH}_{3}$-SCR of $1 \mathrm{Ni6Mn} 3 \mathrm{Ce}-\mathrm{O}$, which was in agreement with the results in Fig. 1. The $\mathrm{NH}_{3}$ SCR reaction on $1 \mathrm{Ni} 6 \mathrm{Mn} 3 \mathrm{Ce}-\mathrm{O}$ may follow $\mathrm{L}-\mathrm{H}$ mechanism, $\mathrm{NH}_{3}$ (a) and $\mathrm{NO}$ (a) reacted to form $\mathrm{N}_{2}$ and $\mathrm{H}_{2} \mathrm{O}$. When $\mathrm{SO}_{2}$ and $\mathrm{H}_{2} \mathrm{O}$ were introduced into the flue gas, $\mathrm{NO}(\mathrm{a})$ was more prone to react with $\mathrm{NH}_{3}$ (a) than $\mathrm{SO}_{2}$. All of these contribute to excellent $\mathrm{H}_{2} \mathrm{O}$ and $\mathrm{SO}_{2}$ resistance.

\section{Discussion and conclusions}

It was commonly accepted that there was an intense correlation between catalytic performance and structural properties, such as morphologies, crystal plans, crystal phases and porous structures. A porous structure provided much surface area and makes the adsorption and diffusion of reactant molecules easy to conduct on the surface of catalysts. In this report, catalysts with different pore structures were created by oxalate route, nanocasting strategy and co-precipitation method. Based on above analysis, catalyst from oxalate route showed best NOx conversion, including NOx conversion and $\mathrm{SO}_{2}$ and $\mathrm{H}_{2} \mathrm{O}$ resistance. Catalyst from oxalate route presented proper ratio of $\mathrm{Mn}^{3+}$, surface oxygen species, surface acidic sites, moderate pore size and specific surface area.

Because the catalytic process over single oxide catalysts was limited, the addition of another component into the system would be favorable. ${ }^{28}$ In this study, cobalt or nickel was added to Mn-Ce composites, which enhanced the interaction between different elements. However, the deNOx performances of 
catalysts were varied based on the added elements. The introduction of nickel leads to the co-existence of Lewis acid sites and Brønsted acid sites. Addition of cobalt leads to much more Lewis acid sites. It has been proved in previous analysis that Brønsted acid sites are better for the resistance of $\mathrm{H}_{2} \mathrm{O}$ and $\mathrm{SO}_{2}$.

Several methods have been developed to reduce the poisonous effect of $\mathrm{H}_{2} \mathrm{O}$ and $\mathrm{SO}_{2}$ to SCR, such as selecting most active support, metal modification, rational design of structure and morphology, ${ }^{1}$ and pre-sulfation. ${ }^{\mathbf{4 0 , 4 1}}$ The mechanism of these methods was to make a balance among redox properties, effective acid sites, and the formation/decomposition of ammonium sulfate, therefore enhancing the deNOx properties and suppressing the blocking effect of $\mathrm{H}_{2} \mathrm{O}$ and $\mathrm{SO}_{2}$. In this study, introducing nickel into $\mathrm{Mn}$-Ce composite gave rise to more Brønsted acid sites, which was responsible for good $\mathrm{H}_{2} \mathrm{O}$ and $\mathrm{SO}_{2}$ resistance.

Different preparation method including oxalate route, nanocasting strategy and traditional co-precipitation were applied to obtain $\mathrm{MnOx}-\mathrm{CeO}_{2}$ mixed oxides. The mesoporous $\mathrm{Mn}-\mathrm{Ce}$ base catalysts prepared from oxalate route showed high deNOx efficiency and good $\mathrm{SO}_{2}$ and $\mathrm{H}_{2} \mathrm{O}$ resistance in the low temperature range. A third dopant such as nickel or cobalt was introduced to the composite to increase $\mathrm{SO}_{2}$ and $\mathrm{H}_{2} \mathrm{O}$ durability. The nickel-manganese-cerium ternary oxides showed the best $\mathrm{SO}_{2}$ and $\mathrm{H}_{2} \mathrm{O}$ durability. The reason can be ascribed to its smaller pores and amorphous structure and proper amount of surface $\mathrm{Mn}^{3+}$ /oxygen species, which could decrease the chemical adsorption of $\mathrm{SO}_{2}$.

\section{Conflicts of interest}

There are no conflicts to declare.

\section{Acknowledgements}

The research was financially supported by the National Key Research and Development Plan (2016YFC0204100, 2016YFC0204103), Control Strategy and Technology Integrated Demonstration of Industrial Source Pollution in Guanzhong area of China (ZDRW-ZS-2017-6-2). The authors also acknowledge the analytical and testing center of Institute of Process Engineering, Chinese Academy of Sciences, for their extensive help in testing of samples.

\section{References}

1 C. Gao, J. W. Shi, Z. Y. Fan, G. Gao and C. M. Niu, Sulfur and Water Resistance of Mn-Based Catalysts for LowTemperature Selective Catalytic Reduction of NOx: a Review, Catalysts, 2018, 8, 11.

2 L. Q. Chen, F. L. Yuan, Z. B. Li, X. Y. Niu and Y. J. Zhu, Synergistic effect between the redox property and acidity on enhancing the low temperature $\mathrm{NH}_{3}$-SCR activity for NOx removal over the $\mathrm{Co}_{0.2} \mathrm{Ce}_{\mathrm{x}} \mathrm{Mn}_{0.8-\mathrm{x}} \mathrm{Ti}_{10}(\mathrm{x}=0-0.40)$ oxides catalysts, Chem. Eng. J., 2018, 354, 393-406.

3 X. Hu, L. Huang, J. Zhang, H. Li, K. Zha, L. Shi, et al., Facile and template-free fabrication of mesoporous 3D nanosphere-like $\mathrm{Mn}_{\mathrm{x}} \mathrm{Co}_{3-\mathrm{x}} \mathrm{O}_{4}$ as highly effective catalysts for low temperature SCR of NOx with $\mathrm{NH}_{3}$, J. Mater. Chem. A, 2018, 6, 2952-2963.

4 L. Li, B. Sun, J. Sun, S. Yu, C. Ge, C. Tang, et al., Novel MnOx$\mathrm{CeO}_{2}$ nanosphere catalyst for low-temperature $\mathrm{NH}_{3}$-SCR, Catal. Commun., 2017, 100, 98-102.

5 C. Li, X. Tang, H. Yi, L. Wang, X. Cui, C. Chu, et al., Rational design of template-free $\mathrm{MnOx}^{-\mathrm{CeO}_{2}}$ hollow nanotube as deNOx catalyst at low temperature, Appl. Surf. Sci., 2018, 428, 924-932.

6 H. Chang, J. Li, X. Chen, L. Ma, S. Yang, J. W. Schwank, et al., Effect of $\mathrm{Sn}$ on $\mathrm{MnOx}-\mathrm{CeO}_{2}$ catalyst for SCR of NOx by ammonia: Enhancement of activity and remarkable resistance to $\mathrm{SO}_{2}$, Catal. Commun., 2012, 27, 54-57.

7 J. Liu, R.-t Guo, M.-y Li, P. Sun, S.-m. Liu, W.-g. Pan, et al., Enhancement of the $\mathrm{SO}_{2}$ resistance of $\mathrm{Mn} / \mathrm{TiO}_{2}$ SCR catalyst by $\mathrm{Eu}$ modification: A mechanism study, Fuel, 2018, 223, 385-393.

8 Z. Liu, X. Feng, Z. Zhou, Y. Feng and J. Li, Ce-Sn binary oxide catalyst for the selective catalytic reduction of $\mathrm{NOx}$ by $\mathrm{NH}_{3}$, Appl. Surf. Sci., 2018, 428, 526-533.

9 K. Zha, S. Cai, H. Hu, H. Li, T. Yan, L. Shi, et al., In Situ DRIFTs Investigation of Promotional Effects of Tungsten

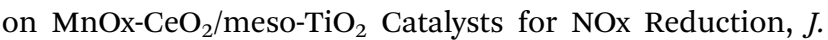
Phys. Chem. C, 2017, 121, 25243-25254.

10 F. Gao, X. Tang, H. Yi, J. Li, S. Zhao, J. Wang, et al., Promotional mechanisms of activity and $\mathrm{SO}_{2}$ tolerance of Co- or Ni-doped $\mathrm{MnOx}^{-\mathrm{CeO}_{2}}$ catalysts for SCR of NOx with $\mathrm{NH}_{3}$ at low temperature, Chem. Eng. J., 2017, 317, 20-31.

11 K. Zha, L. Kang, C. Feng, L. Han, H. Li, T. Yan, et al., Improved NOx reduction in the presence of alkali metals by using hollandite $\mathrm{Mn}$-Ti oxide promoted Cu-SAPO-34 catalysts, Environ. Sci. Nano, 2018, 5, 1408-1419.

12 L. Kang, L. Han, J. He, H. Li, T. Yan, G. Chen, et al., Improved NOx Reduction in the Presence of $\mathrm{SO}_{2}$ by Using $\mathrm{Fe}_{2} \mathrm{O}_{3}$ Promoted Halloysite-Supported $\mathrm{CeO}_{2}-\mathrm{WO}_{3}$ Catalysts, Environ. Sci. Technol., 2019, 53, 938-945.

13 F. Kleitz, S. Hei Choi and R. Ryoo, Cubic Ia3d large mesoporous silica: synthesis and replication to platinum nanowires, carbon nanorods and carbon nanotubes, Chem. Commun., 2003, 2136-2137.

$14 \mathrm{H}$. Liu, L. Wei, R. Yue and Y. Chen, $\mathrm{CrOx}-\mathrm{CeO}_{2}$ binary oxide as a superior catalyst for $\mathrm{NO}$ reduction with $\mathrm{NH}_{3}$ at low temperature in presence of CO, Catal. Commun., 2010, 11, 829-833.

15 J. Liu, X. Li, R. Li, Q. Zhao, J. Ke, H. Xiao, et al., Facile synthesis of tube-shaped Mn-Ni-Ti solid solution and preferable Langmuir-Hinshelwood mechanism for selective catalytic reduction of $\mathrm{NOx}$ by $\mathrm{NH}_{3}$, Appl. Catal., A, 2018, 549, 289-301.

16 Y. Wan, W. Zhao, Y. Tang, L. Li, H. Wang, Y. Cui, et al., NiMn bi-metal oxide catalysts for the low temperature SCR removal of NO with $\mathrm{NH}_{3}$, Appl. Catal., B, 2014, 148-149, 114-122.

17 X. Li, Y. Du, X. Guo, R. Wang, B. Hou and X. Wu, Synthesis of a Novel NiMnTi Mixed Metal Oxides from LDH Precursor 
and Its Catalytic Application for Selective Catalytic Reduction of NOx with $\mathrm{NH}_{3}$, Catal. Lett., 2018, 149, 456-464.

18 H. Chang, X. Chen, J. Li, L. Ma, C. Wang, C. Liu, et al., Improvement of Activity and $\mathrm{SO}_{2}$ Tolerance of Sn-Modified MnOx-CeO $\mathrm{C}_{2}$ Catalysts for $\mathrm{NH}_{3}$-SCR at Low Temperatures, Environ. Sci. Technol., 2013, 47, 5294-5301.

19 B. Thirupathi and P. G. Smirniotis, Co-doping a metal (Cr, $\mathrm{Fe}, \mathrm{Co}, \mathrm{Ni}, \mathrm{Cu}, \mathrm{Zn}, \mathrm{Ce}$, and $\mathrm{Zr}$ ) on $\mathrm{Mn} / \mathrm{TiO}_{2}$ catalyst and its effect on the selective reduction of $\mathrm{NO}$ with $\mathrm{NH}_{3}$ at lowtemperatures, Appl. Catal., B, 2011, 110, 195-206.

20 X. Tang, J. Li, L. Wei and J. Hao, MnOx-SnO ${ }_{2}$ catalysts synthesized by a redox coprecipitation method for selective catalytic reduction of $\mathrm{NO}$ by $\mathrm{NH}_{3}$, Chin. J. Catal., 2008, 29, 531-536.

$21 \mathrm{~S}$. Li, B. Huang and C. $\mathrm{Yu}, \mathrm{A} \mathrm{CeO}_{2}-\mathrm{MnOx}$ core-shell catalyst for low-temperature $\mathrm{NH}_{3}$-SCR of $\mathrm{NO}$, Catal. Commun., 2017, 98, 47-51.

22 L. Chen, X. Niu, Z. Li, Y. Dong, Z. Zhang, F. Yuan, et al., Promoting catalytic performances of Ni-Mn spinel for $\mathrm{NH}_{3}$ SCR by treatment with $\mathrm{SO}_{2}$ and $\mathrm{H}_{2} \mathrm{O}$, Catal. Commun., 2016, 85, 48-51.

23 W. Sun, X. Li, Q. Zhao, M. Tade and S. Liu, $\mathrm{W}_{\alpha} \mathrm{Mn}_{1-\alpha} \mathrm{Ox}$ Catalysts Synthesized by a One-Step Urea Co-precipitation Method for Selective Catalytic Reduction of NOx with $\mathrm{NH}_{3}$ at Low Temperatures, Energy Fuels, 2016, 30, 1810-1814.

24 N. Fang, J. Guo, S. Shu, H. Luo, Y. Chu and J. Li, Enhancement of low-temperature activity and sulfur resistance of $\mathrm{Fe}_{0.3} \mathrm{Mn}_{0.5} \mathrm{Zr}_{0.2}$ catalyst for $\mathrm{NO}$ removal by $\mathrm{NH}_{3}$-SCR, Chem. Eng. J., 2017, 325, 114-123.

25 G. Qi and R. T. Yang, Performance and kinetics study for lowtemperature SCR of $\mathrm{NO}$ with $\mathrm{NH}_{3}$ over $\mathrm{MnOx}-\mathrm{CeO}_{2}$ catalyst, J. Catal., 2003, 217, 434-441.

26 M. Qiu, S. Zhan, H. Yu and D. Zhu, Low-temperature selective catalytic reduction of $\mathrm{NO}$ with $\mathrm{NH}_{3}$ over ordered mesoporous $\mathrm{Mn}_{\mathrm{x}} \mathrm{Co}_{3-\mathrm{x}} \mathrm{O}_{4}$ catalyst, Catal. Commun., 2015, 62, 107-111.

27 P. Zhang, Y. Sun, W. Su, Y. Wei and J. Liu, Low-temperature selective catalytic reduction of $\mathrm{NO}$ with $\mathrm{NH}_{3}$ over Ni-Mn-Ox catalysts, RSC Adv., 2016, 6, 107270-107277.

28 W. Tang, Y. Deng, W. Li, J. Li, G. Liu, S. Li, et al., Importance of porous structure and synergistic effect on the catalytic oxidation activities over hierarchical $\mathrm{Mn}-\mathrm{Ni}$ composite oxides, Catal. Sci. Technol., 2016, 6, 1710-1718.

29 B. Jia, J. Guo, H. Luo, S. Shu, N. Fang and J. Li, Study of NO removal and resistance to $\mathrm{SO}_{2}$ and $\mathrm{H}_{2} \mathrm{O}$ of $\mathrm{MnOx} / \mathrm{TiO}_{2}$, $\mathrm{MnOx} / \mathrm{ZrO}_{2}$ and $\mathrm{MnOx} / \mathrm{ZrO}_{2}-\mathrm{TiO}_{2}$, Appl. Catal., A, 2018, 553, 82-90.
30 Q. Shen, L. Zhang, N. Sun, H. Wang, L. Zhong, C. He, et al., Hollow $\mathrm{MnOx}-\mathrm{CeO}_{2}$ mixed oxides as highly efficient catalysts in NO oxidation, Chem. Eng. J., 2017, 322, 46-55.

31 W. Sun, X. Li, Q. Zhao, J. Mu and J. Chen, Fe-Mn Mixed Oxide Catalysts Synthesized by One-Step Urea-Precipitation Method for the Selective Catalytic Reduction of NOx with $\mathrm{NH}_{3}$ at Low Temperatures, Catal. Lett., 2018, 148, 227-234.

32 D. S. Zhang, L. Zhang, L. Y. Shi, C. Fang, H. R. Li, R. H. Gao, et al., In situ supported MnOx-CeOx on carbon nanotubes for the low-temperature selective catalytic reduction of NO with $\mathrm{NH}_{3}$, Nanoscale, 2013, 5, 1127-1136.

33 Y. Niu, T. Shang, S. Hui, X. Zhang, Y. Lei, Y. Lv, et al., Synergistic removal of $\mathrm{NO}$ and $\mathrm{N}_{2} \mathrm{O}$ in low-temperature SCR process with $\mathrm{MnOx} / \mathrm{Ti}$ based catalyst doped with $\mathrm{Ce}$ and V, Fuel, 2016, 185, 316-322.

34 J. Liu, X. Li, Q. Zhao, J. Ke, H. Xiao, X. Lv, et al., Mechanistic investigation of the enhanced $\mathrm{NH}_{3}$-SCR on cobalt-decorated Ce-Ti mixed oxide: In situ FTIR analysis for structure-activity correlation, Appl. Catal., B, 2017, 200, 297-308.

35 L. Chen, R. Li, Z. Li, F. Yuan, X. Niu and Y. Zhu, Effect of Ni doping in NixMn1-xTi10 $(\mathrm{x}=0.1-0.5)$ on activity and $\mathrm{SO}_{2}$ resistance for $\mathrm{NH}_{3}$-SCR of NO studied with in situ DRIFTS, Catal. Sci. Technol., 2017, 7, 3243-3257.

36 H.-D. Liu, W.-M. Li, R.-L. Yue and Y.-F. Chen, Reaction Mechanism of $\mathrm{NH}_{3}$-Selective Catalytic Reduction for $\mathrm{NO}$ on CrOx-CeO ${ }_{2}$ Binary Oxide, Chin. J. Inorg. Chem., 2013, 29, 2399-2404.

37 T. Zhang, F. Qiu, H. Chang, Y. Peng and J. Li, Novel Wmodified SnMnCeOx catalyst for the selective catalytic reduction of NOx with $\mathrm{NH}_{3}$, Catal. Commun., 2017, 100, 117-120.

38 G. Wu, X. Feng, H. Zhang, Y. Zhang, J. Wang, Y. Chen, et al., The promotional role of $\mathrm{Ni}$ in $\mathrm{FeVO}_{4} / \mathrm{TiO}_{2}$ monolith catalyst for selective catalytic reduction of $\mathrm{NOx}$ with $\mathrm{NH}_{3}$, Appl. Surf. Sci., 2018, 427, 24-36.

39 W. Shan, F. Liu, H. He, X. Shi and C. Zhang, Novel ceriumtungsten mixed oxide catalyst for the selective catalytic reduction of NOx with $\mathrm{NH}_{3}$, Chem. Commun., 2011, 47, 8046-8048.

40 K. Wijayanti, S. Andonova, A. Kumar, J. Li, K. Kamasamudram, N. W. Currier, et al., Impact of sulfur oxide on $\mathrm{NH}_{3}$-SCR over Cu-SAPO-34, Appl. Catal., B, 2015, 166, 568-579.

41 L. Zhang, H. Qu, T. Du, W. Ma and Q. Zhong, $\mathrm{H}_{2} \mathrm{O}$ and $\mathrm{SO}_{2}$ tolerance, activity and reaction mechanism of sulfated $\mathrm{Ni}-$ Ce-La composite oxide nanocrystals in $\mathrm{NH}_{3}$-SCR, Chem. Eng. J., 2016, 296, 122-131. 